\title{
Mechanical properties of the bovine claw horn during lactation
}

\author{
B. Winkler* and J. K. Margerison ${ }^{1}$ \\ *Department of Biological Sciences, University of Plymouth, Plymouth, UK, PL4 8AA \\ †Massey University, Private Bag 11222, Palmerston North, New Zealand
}

\section{ABSTRACT}

Claw horn disorders are one of the main causes of lameness in dairy cows globally. This study aimed to develop material testing techniques to assess changes in the mechanical properties of bovine claw horn $(\mathrm{BCH})$ and to compare these mechanical properties with existing methods of assessing claw horn disorders during lactation. Lameness was also measured through locomotion scoring to assess the clinical significance of changes observed in the scoring for lesions. Experiment 1 used 8 claws collected from four 12 to 18 mo old beef heifers, to develop BCH sample storage methods and techniques to test the mechanical properties of $\mathrm{BCH}$ (puncture resistance and elastic modulus). The increase in the moisture content of $\mathrm{BCH}$ had a significant negative exponential effect on the elastic modulus of the sole and white line claw horn and a linear reduction in the puncture resistance of $\mathrm{BCH}$. Placing $\mathrm{BCH}$ samples in sealed plastic bags and storing them either at $2^{\circ} \mathrm{C}$ or by freezing samples at $-22^{\circ} \mathrm{C}$ did not alter the dry matter content and, consequently, the mechanical properties of the claw horn tissue. In experiment 2, $\mathrm{BCH}$ was collected from 36 lactating dairy cows and mechanical properties were tested using puncture resistance. Puncture resistance of the sole area of the claw horn decreased significantly when hemorrhages in the tested area increased. The puncture resistance of the sole and white line areas decreased at d 160 postpartum when the cows exhibited higher lesion scores and was lower in hind claws that had higher lesion scores when compared with the fore claws. The highest puncture resistance was found at $270 \mathrm{~d}$ postpartum, when the animals were at pasture. Puncture resistance was found to be an effective technique for assessing the effect of period of lactation and increasing hemorrhage levels on the mechanical properties and structural strength of bovine claw horn. It was found to be a good method of comparing changes and differences in mechanical properties and structural strength of $\mathrm{BCH}$ from the sole and white line areas within each claw and dif-

Received April 26, 2011.

Accepted November 23, 2011.

${ }^{1}$ Corresponding author: betinawinkler@hotmail.com ferences between claws. White line BCH consistently had significantly lower puncture resistance compared with the sole. Bovine claw horn with greater levels of hemorrhage or lower puncture resistance, or both, may provide less protection and increase the risk of foreign body penetration, trauma, and secondary infection of the corium of the claw.

Key words: cattle, claw horn, mechanical properties, lameness

\section{INTRODUCTION}

The structure of the bovine claw horn $(\mathbf{B C H})$ and, consequently, its mechanical properties are determined by a combination of factors, such as the composition and chemical bonding of keratin proteins, keratin filaments and filament-associated proteins, along with the composition and amount of the intercellular cementing substance and the arrangement of horn tubules and intertubular space (Mulling et al., 1994; Patan and Budras, 2003). Differences in BCH morphology have been found to exist between the fore and the hind claws (Schmid, 1995) and the hardness of $\mathrm{BCH}$ has been found to decrease between the coronary and the weight bearing border and between the dorsal and the heel areas of the claw (Hinterhofer et al., 2005b). The wall and sole horn have been found to be harder than that of the bulb, whereas the bulb horn showed greater elasticity. The bulb intercellular cementing substance has a high content of phospholipids, indicating that it provides an effective barrier to moisture (Mulling et al., 1994). However, the quality of $\mathrm{BCH}$ has been found to depend on the appropriate supply of nutrients and oxygen to the keratin-producing epidermal cells, which themselves are very susceptible to disturbances in blood circulation within the vessels of the corium (Mulling and Budras, 2002). Hemorrhaging of BCH of the sole and white line areas has been found to increase postpartum (Offer et al.., 2000) which is, in part, directly related to hormonal, metabolic (Tarlton et al. 2002) and postural changes at parturition (Chapinal et al., 2009). During that period, a reduction occurs of the support capability of collagen fibers that suspend the pedal bone within the claw capsule, thus increasing the 
pressure upon the corium particularly in the sole area (Tarlton et al. 2002). Those changes have been demonstrated through the scoring of claw horn lesions by Offer et al. (2000) and Le Fevre et al. (2001). Moreover, claw horn lesion scores have been found to be higher in the hind lateral claws compared with other claws, indicating that the distribution of pressure between individual claws plays an important role in the pathogenesis of claw horn lesions. Animals with a shallow leg and claw angle tended to bear a greater proportion of weight on the hind lateral claws, which increases the risk of developing claw horn lesions and subsequent lameness (Capion et al., 2008). In this study, we aimed to test if the increase in the hemorrhaging of the $\mathrm{BCH}$ is related to changes in the $\mathrm{BCH}$ mechanical properties. Changes in the mechanical properties of the $\mathrm{BCH}$ can compromise its capability to withstand pressure and the protection it confers to the underlying corium. According to Barker et al. (2009) the penetration of the claw by foreign bodies and the formation of abscesses have been found to be a common problem encountered on British dairy farms.

When testing the mechanical properties of the $\mathrm{BCH}$, the testing conditions should be controlled to avoid the loss of moisture from the samples. The changes in the moisture content (MC) of the bovine and equine claw horn had an effect on its hardness, elastic modulus (EM), bending stiffness and fracture toughness (Schmid, 1995; Collins et al., 1998; Baillie et al. 2000; Hinterhofer et al., 2005a,b) and we aimed to test if moisture affected puncture resistance (PR) in the same way. The control of loss of moisture has been achieved by Collins et al. (1998) using triple layers of Parafilm when testing donkey hoof horn and by Hinterhofer et al. (1998) and Kasapi and Gosline (1999) with the use of resealable plastic bags and refrigeration when testing equine hoof horn. The effect of freezing on the mechanical properties of $\mathrm{BCH}$ is relatively unknown. Kasapi and Gosline (1999) did examine the effect of freezing on equine wall horn samples and found no significant effect on bending modulus.

This study aimed to determine the influence of the $\mathrm{MC}$, storage method (refrigerating in plastic bags and freezing), and storage time on the PR and EM of the $\mathrm{BCH}$. The PR test was then used to assess changes in the mechanical properties of $\mathrm{BCH}$ samples in live animals. Bovine claw horn samples were collected during the lactation period from the sole and white line areas of dairy cows and its mechanical properties compared with the claw horn lesion scores of the same animals. The locomotion score was recorded throughout the lactation period to assess the clinical significance of changes observed in the scoring for lesions.

\section{MATERIALS AND METHODS}

\section{Experiment 1-The Effect of Storage Methods and MC on the PR and EM of BCH from Beef Heifers}

Sample Collection and Preparation. All 8 claws from 4 cross-bred beef heifers, aged between 12 and 18 mo, were collected from a local abattoir. The tests were not performed on dairy heifer claws because this category of animal does not get slaughtered regularly and samples were not available. The claws were examined within $12 \mathrm{~h}$ of slaughtering and collection and exhibited normal physiological aspects, showing no visible pathological changes to the wall, white line or sole areas. The claws remained attached to the distal portions of the limb. On the same day of collection, the claws were placed in a vice and the distal 1-mm surface of the sole horn was removed using a wood plane. Using the same method, claw horn samples were taken from the clean areas 2 (white line), 4 , and 5 (sole) according to the International Foot Map (IFM; Shearer et al., 2002), of each claw. They were labeled and stored in sealed plastic bags in a refrigerator $\left(4^{\circ} \mathrm{C}\right)$ until the $\mathrm{BCH}$ samples were tested through PR and tension testing.

$P R$ and $E M$ of the Diaphragm. The PR test was applied using a $\mathrm{P} / 2 \mathrm{~N}$ needle probe on a TA.XT2i Texture Analyzer with a 25-kg load cell (Stable MicroSystems Ltd., Surrey, UK). The BCH samples were held in place between two 15 -mm thick metal plates with a $10-\mathrm{mm}$ diameter hole in the center and the test probe traveled at a speed of $1.0 \mathrm{~mm} / \mathrm{s}$. This test speed was sufficient to enable the material to adapt to the load (Aranwela et al., 1999). The force-displacement curve was recorded at a trigger force of $5 \mathrm{~g}$ and the probe traveled a further $12.0 \mathrm{~mm}$ before returning to the initial position, which was sufficient to permit the puncture of the $\mathrm{BCH}$ samples, allowing the force at puncture to be measured (maximum puncture resistance). The thickness of the $\mathrm{BCH}$ sample at the test area was measured using a micrometer with an accuracy of $0.01 \mathrm{~mm}$. This PR test considered the $\mathrm{BCH}$ sample as a circular thin plate (diaphragm) clamped around its circumference (fixed edges) where the deflection of the plate exceeded the plate thickness and the EM of the diaphragm was calculated according to the method used by Blake (1982), from the equation for maximum lateral deflection of circular plates:

$$
0.1576 \mathrm{q} / \operatorname{Ed}\left(\mathrm{R}_{0} / \mathrm{t}\right)^{4}=\delta / \mathrm{t}+0.583(\delta / \mathrm{t})^{3},
$$

where $\mathrm{q}=$ transverse pressure $=$ puncture force/outer radius of plate ${ }^{2}, \mathrm{Ed}=$ elastic modulus of the diaphragm, $\mathrm{R}_{0}=$ outer radius of plate, $\mathrm{t}=$ plate (diaphragm) thickness, and $\delta=$ maximum deflection of plate. A total of 
10 to 12 tests were completed on area 2, corresponding to the white line, and 5, corresponding to the sole of each claw, according to the IFM (Shearer et al., 2002), and were recorded separately.

EM Measured by Tension Testing. The tension tests were completed to measure the $\mathrm{EM}$ of the $\mathrm{BCH}$ of the sole and white line areas of the claws, using a TA.HDi texture analyzer with a $100-\mathrm{kg}$ load cell (Stable Micro Systems Ltd.) fitted. This test required a dog bone-shaped sample of $\mathrm{BCH}$ to be prepared with a central area of 2 -mm width $\times 20$-mm length $\times 0.05$ to 0.3 mm thickness (Figure 1). The BCH samples were held in place with self-tightening roller grips and the test was completed by moving the grips apart at a speed of $1 \mathrm{~mm} / \mathrm{s}$ until reaching a distance of $30 \mathrm{~mm}$, whereupon they returned to the start position. These tests were completed to $\mathrm{BCH}$ failure and the force-displacement curve was recorded, with the exception of when $\mathrm{BCH}$ tissue failure occurred next to the grips and then the results were discarded. The force-displacement curve resulted in a linear elastic region, followed by a region of non-elastic deformation. The EM was calculated from the linear region by dividing the difference in the force increase (stress) by the sample elongation (strain) for a specific time duration ( $\mathrm{E}=$ stress/strain).

Effect of the $M C$. Bovine claw horn tissue samples of 6 different claws from 4 animals, with a thickness of $0.2 \mathrm{~mm}$, were placed in 5 environments (total of 30 samples) containing relative humidities (RH) corresponding to $11,33,58,75$, and $97 \%$, which were achieved by suspending the samples over solutions of specified salts in desiccators: lithium chloride $(11 \%$ $\mathrm{RH})$, magnesium chloride ( $33 \% \mathrm{RH})$, sodium bromide (58\% RH), sodium chloride (75\% RH), and potassium sulfate $(97 \% \mathrm{RH})$. Bovine claw horn samples were

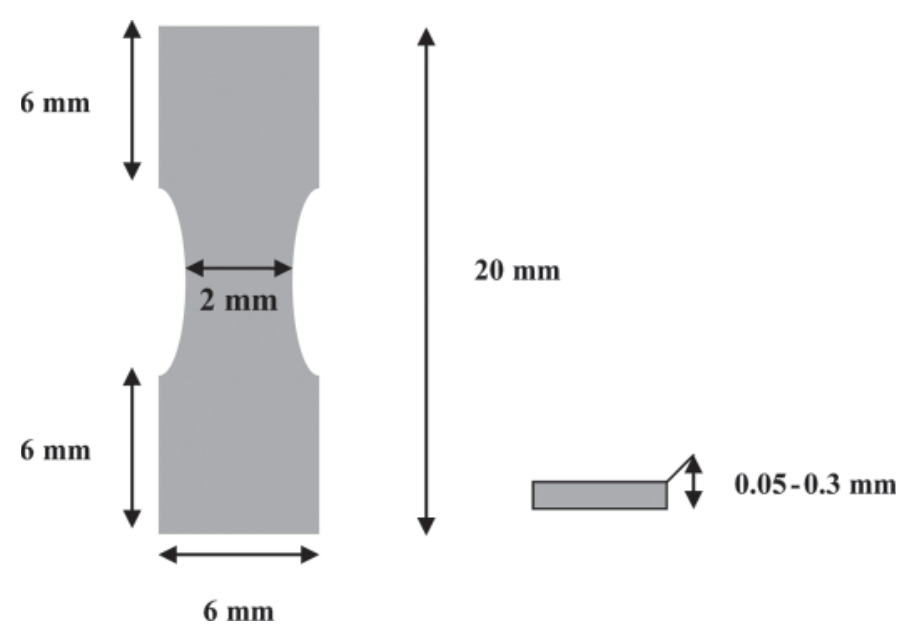

Figure 1. Schematic drawing showing the dimensions of claw horn specimens for the tension test. Diagram is not drawn to scale. left in these environments for $7 \mathrm{~d}$ and then tested for moisture content using a moisture meter (calibrated for $25^{\circ} \mathrm{C}$; Thermoconstanter RTD-33, TH-2; Novasina AG, Lachen, Switzerland). A similar methodology was applied by Collins et al. (1998) when testing hoof horn from donkeys. The PR and tension tests were then completed promptly and, following completion the $\mathrm{BCH}$ samples, were weighed and placed in an oven $\left(100^{\circ} \mathrm{C}\right.$ for $72 \mathrm{~h}$ ) for the determination of the $\mathrm{MC}$ according to the Ministry of Agriculture, Fisheries and Food (MAFF, London, UK; MAFF, 1986). The tension test could only be completed on $\mathrm{BCH}$ samples from the sole area, due to the size and shape of $\mathrm{BCH}$ sample required.

The effect of moisture-rich environments was assessed by placing $\mathrm{BCH}$ samples in distilled water for different periods of time. Bovine claw horn samples $(0.2 \mathrm{~mm}$ thick) were collected from 5 different claws of 4 animals and were tested for PR and EM after collection. Thirty samples, 6 from each claw, were placed in distilled water and 1 sample from each claw was taken out of the distilled water after $3,6,12,24,48$, and $72 \mathrm{~h}$ of soaking, and was tested using PR and tension test techniques. The $\mathrm{BCH}$ samples were assessed for the determination of MC (MAFF, 1986).

Effect of Storage Method and Time on $P R$ and $E M$ of the $\boldsymbol{B C H}$. The effect of storage time before testing of $\mathrm{BCH}$ for mechanical properties was completed using a total of 20 samples of BCH $(0.2 \mathrm{~mm}$ thick), which were collected from 4 claws of 4 different animals. Duplicate samples were placed in self-sealing plastic bags and refrigerated at $2^{\circ} \mathrm{C}$. The PR and EM were measured after $\mathrm{BCH}$ samples had been stored in a refrigerator for $0,48,96,144$, or $192 \mathrm{~h}$. The $\mathrm{BCH}$ samples were left at $20^{\circ} \mathrm{C}$ in the plastic bags for $1 \mathrm{~h}$ before mechanical properties testing, and $\mathrm{BCH}$ samples had MC assessed directly following testing (MAFF, 1986).

The effect of freezing on the PR and EM was assessed by testing $\mathrm{BCH}$ samples collected from 6 different claws of 4 animals on the day of collection and after storage in resealable plastic bags (total of 24 samples). The $\mathrm{BCH}$ samples were stored at $-22^{\circ} \mathrm{C}$ for 1,7 , and $24 \mathrm{~d}$. The bags of $\mathrm{BCH}$ samples were taken out of the freezer and left to defrost at $20^{\circ} \mathrm{C}$ for $4 \mathrm{~h}$, after which PR and tension tests were completed. Bovine claw horn samples had MC assessed directly following testing (MAFF, 1986).

\section{Experiment 2-The Changes in the Mechanical Properties of $\mathrm{BCH}$ of Dairy Cows During Lactation}

The aim of this experiment was to use PR and EM to assess changes in the mechanical properties of $\mathrm{BCH}$ collected from lactating dairy cows. 
Animals, Housing, and Diets. A total of 36 multiparous Holstein-Friesian dairy cows were selected at random, according to calving date, from the University of Plymouth (Plymouth, UK) dairy herd. The cows entered the experiment at parturition. The experiment started in the autumn, from the end of September to December, and ended in the summer when the cows reached 270 DIM. The cows were housed together in straw yards prepartum and received the same dry cow diet, which consisted of barley straw, grass silage, and $2 \mathrm{~kg}$ of a dry cow supplement. After parturition, the cows were housed in 42 freestalls (cubicles) fitted with rubber mats bedded with clean sawdust. The walkways were solid concrete with grooves and were cleaned with a tractor twice daily. The cows were milked twice daily. The cows were offered TMR ad libitum once daily, which consisted of grass and forage maize silage (50:50 ratio), $2.5 \mathrm{~kg}$ of a $38 \% \mathrm{CP}$ compound and $2 \mathrm{~kg}$ of rolled wheat, with the addition of macro- and micronutrients. The cow diet components and composition are presented in Table 1 . In addition, the cows received a maximum of 4 $\mathrm{kg}$ of fresh matter/head of a dairy compound feed $(22 \%$ $\mathrm{CP}$ ) at milking twice daily ( $8 \mathrm{~kg}$ of fresh matter/head per day). All of the cows were housed until 160 DIM, then turned out to pasture, grazed ad libitum, milked twice daily, and received $<4 \mathrm{~kg}$ of fresh matter/head per day of a dairy compound feed $(18 \% \mathrm{CP})$. The cows achieved a mean milk yield of $8,500 \mathrm{~kg}$ per cow over a 305-d lactation.

PR of the Claw Horn from the Dairy Cows. Bovine claw horn samples were collected from area 2 (white line), 4, and 5 (sole) according to the IFM (Shearer et al., 2002) from the lateral claws $(\mathrm{n}=4)$ of all hooves of the 36 dairy cows at 30,60, 160 and 270 DIM. The first outer layer of $\mathrm{BCH}(1-2 \mathrm{~mm})$ was discarded and a $\mathrm{BCH}$ sample of between 0.05 and

Table 1. Ingredients and nutrient composition of the lactating cow diet

\begin{tabular}{lr}
\hline Component & Quantity \\
\hline Ingredient (kg of fresh matter/animal per day) & \\
Grass silage & 20.00 \\
Maize silage & 17.40 \\
Compound (38\% CP) plus chelated minerals & 2.50 \\
Wheat & 4.00 \\
Minerals & 0.08 \\
Dairy compound added to diet (22\% CP) & 2.00 \\
Parlor dairy compound (22\% CP) & $\leq 8.00$ \\
Composition (DM) & \\
DM (\%) & 40.00 \\
ME (MJ/kg) & 11.30 \\
CP (\%) & 17.30 \\
NDF (g/kg) & 314.77 \\
Starch (g/kg) & 213.65 \\
Sugar (g/kg) & 68.99 \\
DCAD balance (mEq) & 396.20 \\
\hline
\end{tabular}

$0.2 \mathrm{~mm}$ thickness was collected using a wood plane; the sample was then placed directly into a resealable labeled plastic bag and placed in a refrigerator at $2^{\circ} \mathrm{C}$ until analysis. Bovine claw horn samples were tested for PR at physiological MC, which was considered the best environmental optimum for testing the mechanical properties of equine hoof horn in vivo (Hinterhofer et al.., 1998). Bovine claw horn samples were assessed for MC at 160 DIM following PR testing (MAFF, 1986).

Locomotion, Lesion Scoring, and Claw Measurements. All cows were assessed for locomotion score twice weekly from parturition onwards, by the same observer and using a 5 -point scoring system $(1=$ no abnormality of gait, $2=$ tender/hardly noticeable change of gait, $3=$ slightly lame, $4=$ markedly lame, and $5=$ severely lame, not weight bearing on affected limb), according to Manson and Leaver (1988). The following factors were assessed when scoring cows for lameness: the ease of assessing which leg was affected, the degree and timing of the head movement, the degree of sinking of the sound quarter, the changes in the stride length, the abduction or adduction of the hind legs and arching of the back. The cows were observed after leaving the milking parlor and when walking in a straight line. The claw horn lesions and claw characteristics were measured at $30,60,160$, and 270 DIM before the collection of claw horn samples for PR testing. The cows were restrained in a hoof trimming crush. The level of sole and white line hemorrhages and sole ulcers were scored using an intensity scale of 0 to 5 for hemorrhages $(1=$ diffuse red in horn, $2=$ stronger red coloration, $3=$ deep dense red, $4=$ port coloration, and $5=$ red raw/possibly fresh blood) and 6 to 8 for ulcers $(6=$ corium exposed, $7=$ severe ulcer $/$ major loss of horn, and $8=$ infected sole ulcer) according to Leach et al. (1998). An individual animal total lesion score for each claw was calculated by assessing the size of the affected area and multiplying it by the hemorrhaging/ulcer score. The size of the affected area was assessed digitally and calculated as a percentage of the total claw area. White line and sole areas were scored separately for each claw. All other claw disorders, such as digital dermatitis, were also recorded.

The monthly wall horn growth and wear rates were calculated as described by Clark and Rakes (1982) and Telezhenko et al. (2009). The growth and wear rates were measured on the abaxial walls of the right front and rear lateral claws at 60, 160, and $270 \mathrm{~d}$ postpartum. A mark was made with a soldering iron on the claw wall $2 \mathrm{~cm}$ below the coronary border (starting at d 30 postpartum). The distances from the coronary border to the mark and from the mark to the distal end of the wall were measured. A new mark was made $2 \mathrm{~cm}$ below the coronary border every time the claws were mea- 


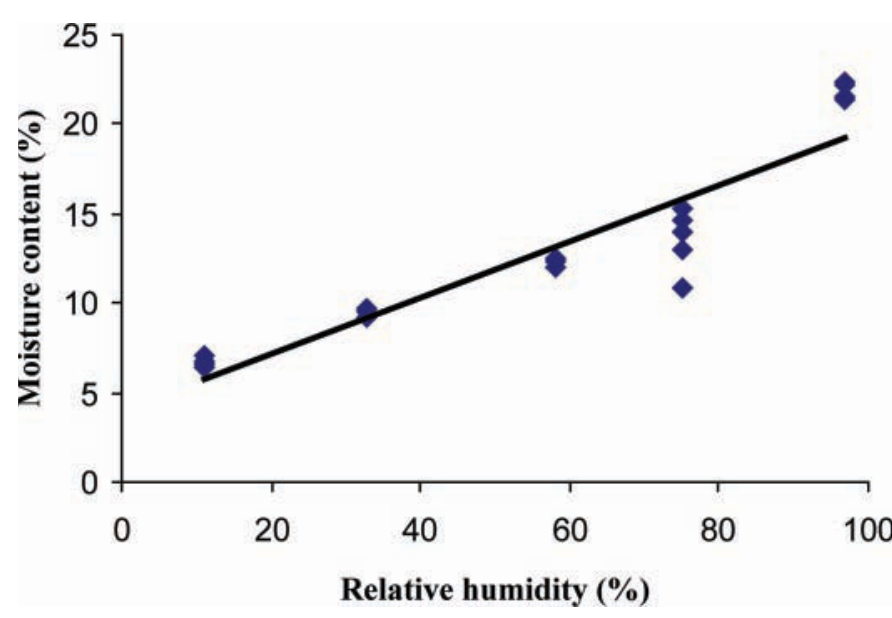

Figure 2. Effect of environments with different relative humidities $(\mathrm{RH})$ on the moisture content (MC) of the samples of bovine claw horn collected from the claws of 12- to 18-mo-old beef heifers $(\mathrm{n}=30) ; \mathrm{MC}$ $(\%)=4.0933+0.1566 \mathrm{RH}(\%)\left(\mathrm{R}^{2}=0.87, P=0.000\right)$. Color version available in the online PDF.

sured. A monthly growth and wear rate was estimated from these measurements. The hoof angle, length of the dorsal claw wall, height of the abaxial wall, and height of the heel were measured on the right front and rear lateral claws using the procedure described by Boelling and Pollott (1998). The recording times were d 160 and 270 postpartum. Hoof angle was measured in degrees with a protractor. The length of the dorsal wall was measured as the distance between the dorsal hairline and the tip of the toe $(\mathrm{mm})$. The abaxial wall height was measured at the posterior part of the wall

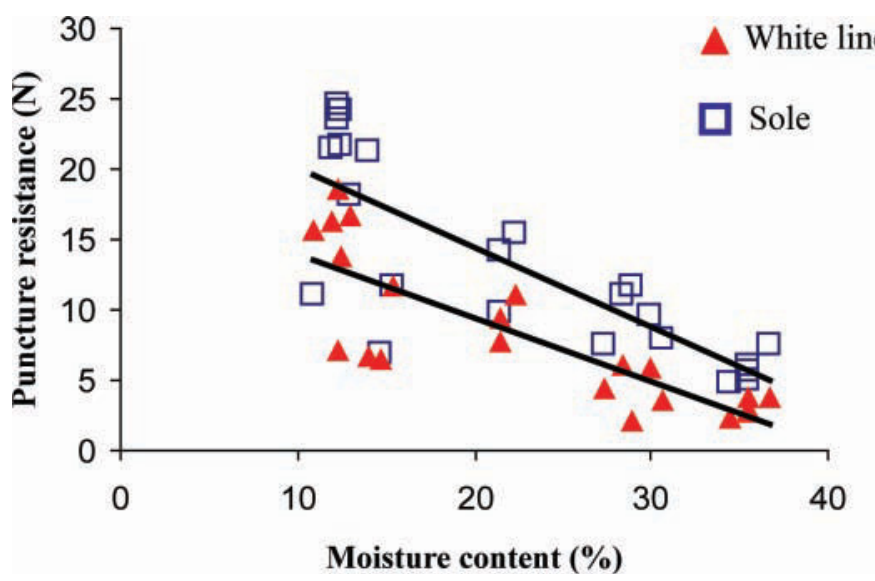

Figure 3. Effect of moisture content (MC) on the puncture resistance (PR) of sole and white line areas of bovine claw horn samples collected from the claws of 12 - to 18 -mo-old beef heifers $(\mathrm{n}=30)$ Puncture resistance of the sole horn $(\mathrm{N})=25.755-0.5635 \mathrm{MC}(\%)$ $\left(\mathrm{R}^{2}=0.63, P=0.000\right) ; \mathrm{PR}$ of the white line horn $(\mathrm{N})=18.491$ $0.4526 \mathrm{MC}(\%)\left(\mathrm{R}^{2}=0.67, P=0.000\right)$. Color version available in the online PDF. as the distance between the hairline and the sole wall border. The height of the heel was measured as the distance between the posterior distal border of the heel horn and the hairline at the rear of the claw. No other routine claw trimming, other than sample collection, was performed during the experimental period.

\section{Statistical Analysis}

In Experiment 1, claw horn MC, PR, EM of the diaphragm, and EM by tension testing (dependent variables) were found to be normally distributed. The effects of time that $\mathrm{BCH}$ samples were soaked in distilled water and the time $\mathrm{BCH}$ were stored in a refrigerator or stored frozen (independent variables) were analyzed using general linear modeling (GLM)-ANOVA and means were compared using the Tukey test (95\% CI, $P$ $<0.05$; Minitab 13.0). The thickness of the samples was used as a covariate using analysis of covariance (ANCOVA) when PR data was analyzed. The effects of RH (independent variable) on $\mathrm{MC}$ and $\mathrm{MC}$ (independent variable) on $\mathrm{PR}$ of the sole and white line areas, EM of the diaphragm of the sole and white line areas, and EM by tension testing were assessed using polynomial regression analysis.

Experiment 2 was a repeated measurement design, using individual cows as observations. The parameters were compared by collection period and claws, using GLM-ANOVA. In the model cow, collection period and claw were used as independent variables. Parity (number of lactations) was found not to have a significant effect on lesion score of the sole and white line areas, PR, claw measurements, and claw horn MC and was left out of the model. The thickness of the samples was used as a covariate using ANCOVA when PR data was ana-

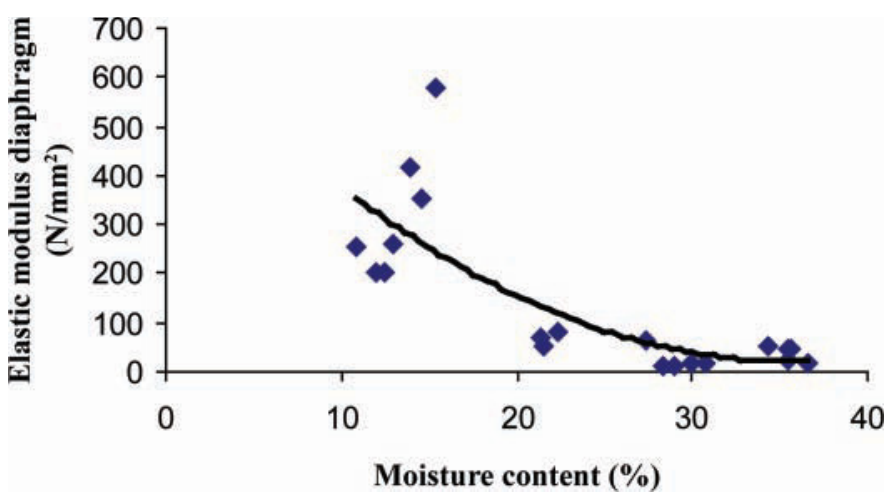

Figure 4. Effect of moisture content (MC) on the elastic modulus of the diaphragm of the sole area of bovine claw horn samples collected from the claws of 12 - to 18 -mo-old beef heifers $(\mathrm{n}=30)$. Elastic modulus of the diaphragm of the sole horn $\left(\mathrm{N} / \mathrm{mm}^{2}\right)=709.25-38.49$ $\mathrm{MC}(\%)+0.53814 \mathrm{MC}(\%)^{2}\left(\mathrm{R}^{2}=0.60, P=0.000\right)$. Color version available in the online PDF. 
Table 2. Moisture content (MC), maximum puncture resistance, elastic modulus (EM) of the diaphragm, and elastic modulus by tension testing of bovine claw horn samples collected from the sole and white line areas of the claws of four 12- to 18-mo-old beef heifers after soaking in distilled water for different periods of time (number of claws $=5$, total number of samples $=30$ )

\begin{tabular}{|c|c|c|c|c|c|c|c|c|c|}
\hline Item & \multicolumn{7}{|c|}{ Soaking time $(\mathrm{h})$} & SEM & $P$-value \\
\hline $\mathrm{MC}(\%)$ & $29.05^{\mathrm{a}}$ & $35.15^{\mathrm{b}}$ & $35.52^{\mathrm{b}}$ & $35.90^{\mathrm{b}}$ & $35.14^{\mathrm{b}}$ & $34.92^{\mathrm{b}}$ & $34.50^{\mathrm{b}}$ & 0.737 & 0.000 \\
\hline Sole $(\mathrm{N})$ & $7.46^{\mathrm{ab}}$ & $8.56^{\mathrm{a}}$ & $6.79^{\mathrm{ab}}$ & $6.75^{\mathrm{ab}}$ & $7.71^{\mathrm{ab}}$ & $7.65^{\mathrm{ab}}$ & $6.58^{\mathrm{b}}$ & 0.447 & 0.043 \\
\hline White line $(\mathrm{N})$ & 3.69 & 4.28 & 3.82 & 3.35 & 4.15 & 3.31 & 3.49 & 0.24 & 0.430 \\
\hline \multicolumn{10}{|l|}{ EM of the diaphragm } \\
\hline \multicolumn{10}{|l|}{ EM by tension testing } \\
\hline Sole $\left(\mathrm{N} / \mathrm{mm}^{2}\right)$ & 116.9 & 221.6 & 232.7 & 206.7 & 243.1 & 274.4 & 188.7 & 39.49 & 0.168 \\
\hline White line $\left(\mathrm{N} / \mathrm{mm}^{2}\right)$ & - & 274.3 & 250.2 & 174.1 & 251.0 & 304.8 & 101.8 & 61.42 & 0.474 \\
\hline
\end{tabular}

${ }^{\mathrm{a}, \mathrm{b}}$ Means within a row followed by differing superscript letters differ $(P<0.05)$.

lyzed. The comparison of means was completed using the Tukey test $(95 \% \mathrm{CI}, P<0.05)$. The lesion score of the sole and white line areas, PR, claw measurements, and claw horn MC data were dependent variables in the model. The lesion score data was normalized by $\log 10$ transformation before analysis; all other variables were normally distributed. Polynomial regression analyses were used to assess the effect of number of days postpartum (independent variable) on locomotion score data (dependent variable). Parity was compared with locomotion score at 90 DIM using GLM-ANOVA. Pearson correlation was used to compare the parameters locomotion score, lesion score, claw measurements, $\mathrm{PR}$, and MC.

\section{RESULTS}

\section{Experiment 1-Effect of MC and Freezing on PR and EM}

The placing of $\mathrm{BCH}$ samples in chambers with increasing levels of $\mathrm{RH}$ resulted in an increase $(P=0.000)$

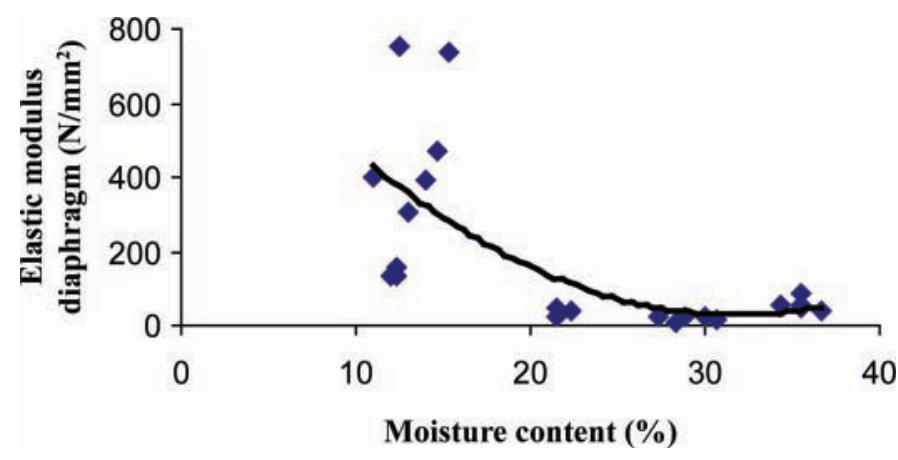

Figure 5. Effect of the moisture content (MC) on the elastic modulus of the diaphragm of the white line area of bovine claw horn samples collected from the claws of 12 - to 18 -mo-old beef heifers $(\mathrm{n}=30)$. Elastic modulus of the diaphragm of the white line area of the horn $\left(\mathrm{N} / \mathrm{mm}^{2}\right)=968.26-59.099 \mathrm{MC}(\%)+0.9288 \mathrm{DM}(\%)^{2}\left(\mathrm{R}^{2}=0.47, P\right.$ $=0.002)$. Color version available in the online PDF. in the $\mathrm{MC}$ of the $\mathrm{BCH}$ samples, ranging from 6.39 to $22.31 \%\left(\mathrm{R}^{2}=0.87\right.$; Figure 2$)$. The increase in BCH MC (\%) from 10.92 to $36.67 \%$ resulted in a linear decrease $(P=0.000)$ in the PR of BCH collected from the sole $\left(R^{2}=0.63\right)$ and white line $\left(R^{2}=0.67\right.$; Figure 3$)$. With the increase in $\mathrm{MC}$, the $\mathrm{BCH}$ sample changed from a brittle to an elastic behavior, resulting in a quadratic decrease in the EM of the diaphragm of the sole $(P=$ $0.000 ; \mathrm{R}^{2}=0.60$; Figure 4$)$ and white line $(P=0.002$; $\mathrm{R}^{2}=0.47$; Figure 5$)$. The increase in the BCH MC was associated with an exponential decrease in the EM $(\mathrm{N} /$ $\left.\mathrm{mm}^{2}\right)$ by tension testing of the sole horn $\left(P=0.000 ; \mathrm{R}^{2}\right.$ $=0.81$; Figure 6 ).

The MC of the claw samples increased $(P=0.001)$ from 29.05 to $35.15 \%$ after $3 \mathrm{~h}$ of soaking in distilled water. The maximum $\mathrm{PR}$ of $\mathrm{BCH}$ from the sole decreased following $72 \mathrm{~h}$ of soaking $(P=0.043)$, but had no effect $(P=0.403)$ on the PR of BCH from the white line. The EM of the diaphragm $(P=0.910$ sole, 0.285 white line $)$ and EM by tension testing of the sole $(P=0.168)$ and white line areas $(P=0.474)$ were not affected by soaking $\mathrm{BCH}$ samples in distilled water (Table 2 ).

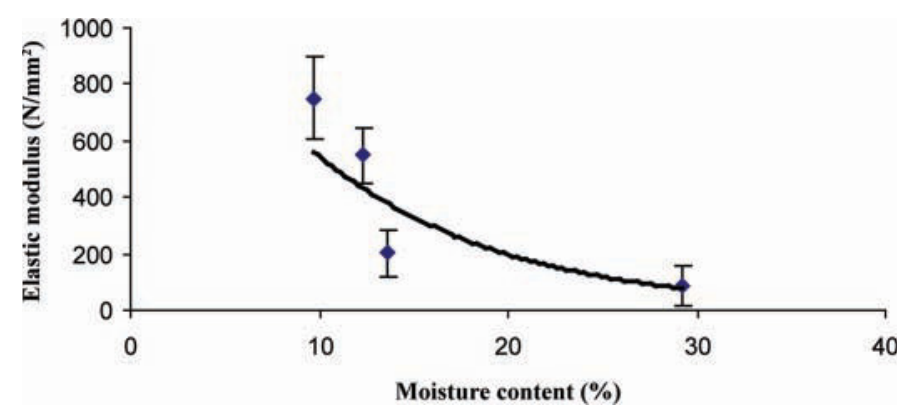

Figure 6. Effect of moisture content (MC) on the elastic modulus by tension testing of the sole horn of bovine claw horn samples collected from the claws of 12 - to 18 -mo-old beef heifers $(\mathrm{n}=30)$. Elastic modulus of the sole horn $\left(\mathrm{N} / \mathrm{mm}^{2}\right)=1497.8 \mathrm{e}^{-0.1012 \mathrm{MC}}\left(\mathrm{R}^{2}=0.81, P=\right.$ 0.000 ). Color version available in the online PDF. 
Table 3. Effect of the number of days horn samples were stored in a refrigerator $\left(2^{\circ} \mathrm{C}\right)$ to analysis of the moisture content (MC), puncture resistance, diaphragm elastic modulus (EM), and elastic modulus by tension testing of bovine claw horn samples taken from the sole and white line area of four 12- to 18-mo-old beef heifers (number of claws $=4$, total number of samples $=20$ )

\begin{tabular}{|c|c|c|c|c|c|c|c|}
\hline \multirow[b]{2}{*}{ Item } & \multicolumn{5}{|c|}{ Days until analysis } & \multirow[b]{2}{*}{ SEM } & \multirow[b]{2}{*}{$P$-value } \\
\hline & 0 & 2 & 4 & 6 & 8 & & \\
\hline $\mathrm{MC}(\%)$ & 27.46 & 27.95 & 27.12 & 28.75 & 28.89 & 0.568 & 0.182 \\
\hline \multicolumn{8}{|l|}{ Puncture resistance } \\
\hline Sole $(N)$ & 8.78 & 10.40 & 10.13 & 9.81 & 9.61 & 0.762 & 0.379 \\
\hline White line $(\mathrm{N})$ & 4.95 & 6.40 & 6.08 & 6.51 & 6.90 & 0.662 & 0.719 \\
\hline \multicolumn{8}{|l|}{ EM of the diaphragm } \\
\hline Sole $\left(\mathrm{N} / \mathrm{mm}^{2}\right)$ & 28.75 & 29.96 & 28.25 & 31.08 & 29.74 & 5.379 & 0.459 \\
\hline White line $\left(\mathrm{N} / \mathrm{mm}^{2}\right)$ & 26.86 & 19.87 & 24.01 & 21.07 & 15.37 & 3.494 & 0.145 \\
\hline \multicolumn{8}{|l|}{ EM by tension testing } \\
\hline Sole $\left(\mathrm{N} / \mathrm{mm}^{2}\right)$ & 158.2 & 148.1 & 226.3 & 125.8 & 175.5 & 43.36 & 0.401 \\
\hline White line $\left(\mathrm{N} / \mathrm{mm}^{2}\right)$ & 91.8 & 159.5 & 218.9 & 143.3 & 194.1 & 37.27 & 0.273 \\
\hline
\end{tabular}

The storage of samples [i.e., number of days (1 to 8) taken to analyze $\mathrm{BCH}$ samples; Table 3] had no effect on the $\mathrm{MC}(P=0.182)$, the $\mathrm{PR}(P=0.379$ sole, 0.719 white line), the EM of the diaphragm $(P=0.459$ sole, 0.145 white line), or the EM by tension testing of $\mathrm{BCH}$ collected from the sole $(P=0.401)$ or white line areas $(P=0.273)$. Similarly, the freezing $\left(-22^{\circ} \mathrm{C}\right)$ of $\mathrm{BCH}$ samples for up to $30 \mathrm{~d}$ (Table 4 ) had no effect on the MC $(P=0.117)$, the PR $(P=0.417$ sole, 0.632 white line), or the EM of the diaphragm of $\mathrm{BCH}$ collected from the sole $(P=0.974)$ or white line areas $(P=$ $0.475)$. An increase $(P=0.000)$ occurred in the EM by tension testing of $\mathrm{BCH}$ taken from the sole after $\mathrm{BCH}$ had been frozen for $30 \mathrm{~d}$ (Table 4).

\section{Experiment 2-Claw Horn Lesions, Locomotion, and Lesion Scores of the Sole and White Line Areas of the Claw Horn in the Postpartum Period}

Among the 35 cows that completed the experiment, 1 cow had displaced abomasum and was removed from the experiment; 4 cows (11.4\%) never became lame, exhibiting locomotion score between 1 and 2; 10 cows $(28.6 \%)$ had a maximum locomotion score of 3 , indicating only slight lameness; and 21 cows $(60.0 \%)$ were severely lame, corresponding to locomotion scores of 4 to 5. Clinical alterations recorded during the experimental period are presented in Table 5. Lesions such as sole ulcers, white line abscedation, interdigital hyperplasia, and a swollen carpal joint caused severe locomotion score (5). Severe sole hemorrhages caused intermediate to high levels of locomotion score $(2,3$, and 4$)$. Some cows diagnosed with digital dermatitis did not show alteration of the gait and some presented intermediate to high levels of locomotion score $(1,2,3$, and 4).

The effect of number of lactation on locomotion score was analyzed at d 90 postpartum, when the cows exhibited the highest mean locomotion scores. The locomotion score at d 90 postpartum increased with the lactations ( 2 to $7 ; P=0.047$ ) but the variation of data was high $\left(\mathrm{R}^{2}=0.19\right)$. Locomotion score was found to have a nonlinear relationship $(P=0.000)$ with stage of

Table 4. Effect of the number of days the samples were stored frozen $\left(-22^{\circ} \mathrm{C}\right)$ on the moisture content $(\mathrm{MC})$, puncture resistance, elastic modulus (EM) of the diaphragm, and elastic modulus by tension testing of the sole and white line areas of bovine claw horn of four 12- to 18-mo-old beef heifers (number of claws $=6$, total sample number $=18$ )

\begin{tabular}{|c|c|c|c|c|c|c|}
\hline \multirow[b]{2}{*}{ Item } & \multicolumn{4}{|c|}{ Days stored frozen } & \multirow[b]{2}{*}{ SEM } & \multirow[b]{2}{*}{$P$-value } \\
\hline & 0 & 1 & 7 & 30 & & \\
\hline $\mathrm{MC}(\%)$ & 27.66 & - & - & 25.78 & 0.221 & 0.117 \\
\hline \multicolumn{7}{|l|}{ Puncture resistance } \\
\hline Sole $(\mathrm{N})$ & 8.34 & 8.72 & 9.86 & 9.10 & 0.660 & 0.417 \\
\hline White line $(\mathrm{N})$ & 6.21 & 6.63 & 7.44 & 7.10 & 0.701 & 0.632 \\
\hline \multicolumn{7}{|l|}{ EM of the diaphragm } \\
\hline Sole $\left(\mathrm{N} / \mathrm{mm}^{2}\right)$ & 33.75 & 35.63 & 36.91 & 34.47 & 5.100 & 0.974 \\
\hline White line $\left(\mathrm{N} / \mathrm{mm}^{2}\right)$ & 29.80 & 36.78 & 40.63 & 36.75 & 4.844 & 0.475 \\
\hline \multicolumn{7}{|l|}{ EM by tension testing } \\
\hline Sole $\left(\mathrm{N} / \mathrm{mm}^{2}\right)$ & $144.4^{\mathrm{b}}$ & $268.3^{\mathrm{ab}}$ & $251.1^{\mathrm{ab}}$ & $403.1^{\mathrm{a}}$ & 42.53 & 0.000 \\
\hline White line $\left(\mathrm{N} / \mathrm{mm}^{2}\right)$ & 116.6 & 136.5 & 292.7 & 330.7 & 67.21 & 0.101 \\
\hline
\end{tabular}

${ }^{\mathrm{a}, \mathrm{b}}$ Means within a row followed by differing superscript letters differ $(P<0.001)$. 
Table 5. Prevalence of claw and leg disorders associated with lameness, observed on dairy cows $(\mathrm{n}=35)$ during the experimental period (DIM 50 to 270)

\begin{tabular}{lcc}
\hline Claw or leg disorder & $\begin{array}{c}\text { No. of cows } \\
\text { affected }\end{array}$ & $\begin{array}{c}\text { Prevalence } \\
(\%)\end{array}$ \\
\hline Digital dermatitis & 8 & 22.9 \\
Severe sole hemorrhage & 10 & 28.6 \\
Sole ulcers & 6 & 17.1 \\
White line fissure with abscedation & 2 & 5.7 \\
Acute laminitis due to sudden diet change & 1 & 2.9 \\
Interdigital hyperplasia & 1 & 2.9 \\
Proximal lesions causing lameness & 1 & 2.9 \\
Lesion on udder & 1 & 2.9 \\
Swollen carpal joint & 1 & \\
\hline
\end{tabular}

lactation $\left(\mathrm{R}^{2}=0.85\right.$; Figure 7$)$, increasing between parturition and 30 and 90 DIM, and beginning to decrease by 120 DIM.

The lesion score of $\mathrm{BCH}$ from the sole increased $(P$ $=0.002)$ between $\mathrm{d} 30$ and 60 DIM, and decreased from 160 DIM. The stage of lactation had no effect $(P$ $=0.305)$ on lesion score of the white line (Table 6 ). The hind right and left lateral claws had higher $(P=$ 0.000) sole lesion scores compared with the fore lateral and hind medial claws at 60, 160, and 270 DIM (Table $7)$. The hind left lateral claws had higher $(P=0.001)$ white line lesion scores at 60 DIM compared with all fore claws and had higher lesion scores at 160 and 270 DIM $(P=0.000$ and 0.002$)$ compared with the hind medial claws (Table 7). The lesion scores of the sole and white line were correlated $(P=0.001 ; \mathrm{r}=0.33)$ and a correlation existed between the lesion scores of the hind left lateral claws, the lesion scores of the hind right lateral claws $(\mathrm{r}=0.46$ and $0.47 ; P=0.012)$, the lesion scores of individual cows at 160 DIM $(\mathrm{r}=0.44 ; P$ $=0.049$ ), and the locomotion scores at 270 DIM.

Claw Horn Growth and Claw Characteristics. A difference $(P=0.000)$ was observed in the claw length, heel height, and wall horn growth rate of the fore right lateral claw and hind right lateral claw at 160 DIM compared with 270 DIM, when the cows were grazed at pasture (Table 8). The wall horn growth rate and dorsal border length increased, whereas the heel height decreased in fore and hind lateral claws when the animals were grazed at pasture compared with the period they were housed in freestalls.

The hind right lateral claw length at 160 and 270 DIM was positively correlated with lesion score $(\mathrm{r}=0.41$ and 0.46 , respectively; $P=0.038$ and 0.022 ). The $P R$ of fore

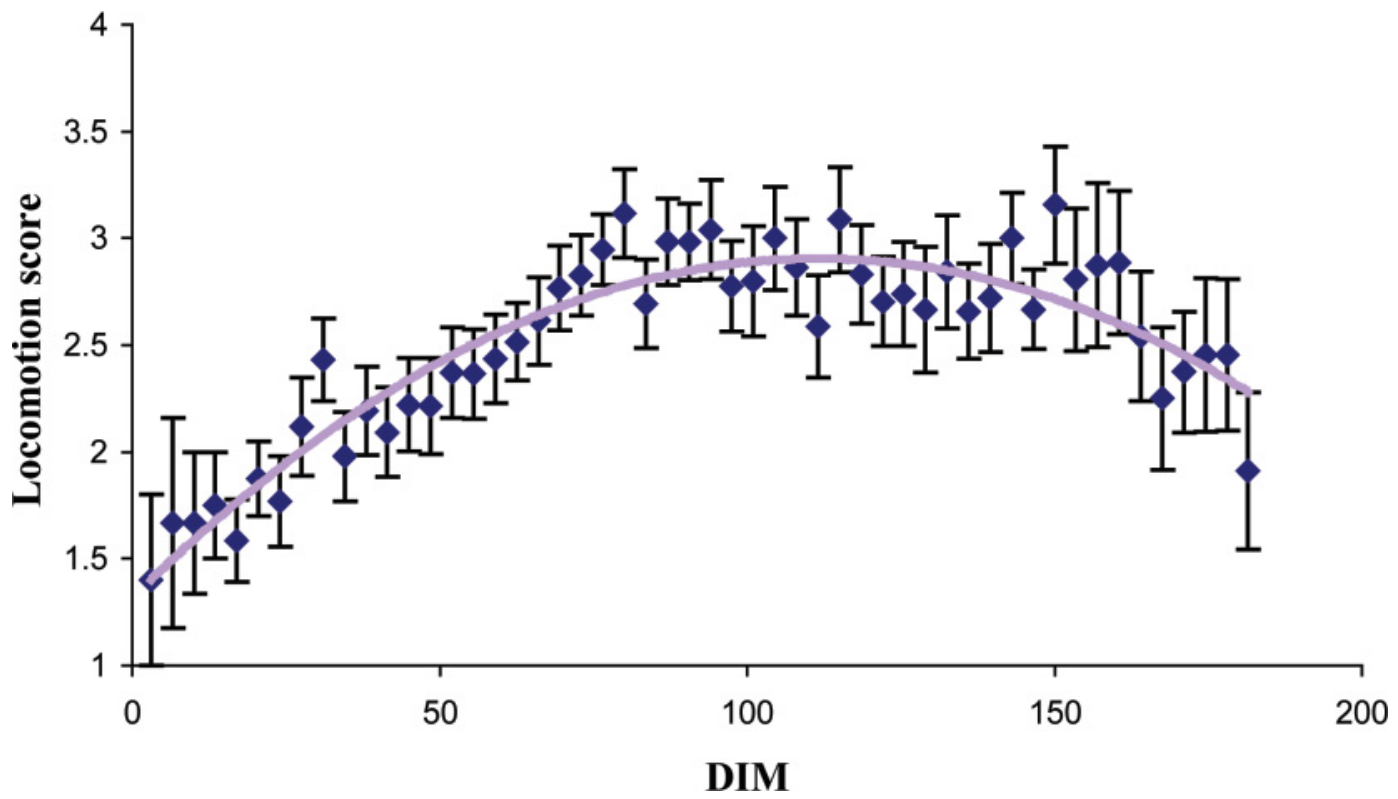

Figure 7. Mean locomotion score $(1=$ no abnormality of gait, $2=$ tender/hardly noticeable change of gait, $3=$ slightly lame, $4=$ markedly lame, and $5=$ severely lame, not weight bearing on affected limb) of multiparous dairy cows $(\mathrm{n}=35)$ at 0 to 180 DIM. Locomotion score $=$ -0.0001 stage of lactation ${ }^{2}+0.0285$ stage of lactation $+1.3159\left(\mathrm{R}^{2}=0.85, P=0.000\right)$. Color version available in the online PDF. 
Table 6. Total lesion score of all claws $(n=8)$ and puncture resistance of lateral claws $(n=4)$ of the sole and white line claw horn of dairy cows $(\mathrm{n}=35)$ at $30,60,160$, and 270 DIM

\begin{tabular}{|c|c|c|c|c|c|c|}
\hline \multirow[b]{2}{*}{ Item } & \multicolumn{4}{|c|}{ DIM } & \multirow[b]{2}{*}{ SEM } & \multirow[b]{2}{*}{$P$-value } \\
\hline & 30 & 60 & 160 & 270 & & \\
\hline White line & 1,292 & 1,716 & 1,286 & 1,483 & 167.1 & 0.305 \\
\hline \multicolumn{7}{|c|}{ Puncture resistance $(\mathrm{N})$} \\
\hline Sole & $8.543^{\mathrm{b}}$ & $8.345^{\mathrm{bc}}$ & $7.755^{\mathrm{c}}$ & $8.983^{\mathrm{a}}$ & 0.150 & 0.000 \\
\hline
\end{tabular}

${ }^{\mathrm{a}-\mathrm{c}}$ Means within rows followed by differing superscript letters differ $(P<0.01)$.

lateral claws at 30 DIM was negatively correlated with the BCH wear rate at 160 DIM $(\mathrm{r}=-0.47)$.

$P R$ of the Sole and White Line Areas of the Claw Horn in the Postpartum Period. The mean $\mathrm{PR}$ of $\mathrm{BCH}$ of the sole decreased in $\mathrm{BCH}$ samples that had higher hemorrhage scores $(\mathbf{H S})[\mathrm{HS} 0=$ no hemorrhage: $8.72 \mathrm{~N} \pm$ 0.078; HS1: $8.53 \mathrm{~N} \pm 0.104$; HS2: 8.06 $\mathrm{N} \pm$ 0.125; HS3: $7.75 \mathrm{~N} \pm 0.151$; HS4: $6.08 \mathrm{~N} \pm 0.331$ HS5 (severe hemorrhage): $4.99 \mathrm{~N} \pm 0.460$; all group values differed, $P=0.000]$. The $\mathrm{PR}$ of sole horn was lower $(P=0.000)$ at 160 DIM compared with 30 and 270 DIM. The maximum PR of the sole horn was negatively correlated $(P=0.001)$ with the lesion score of the sole area $(\mathrm{r}=-0.24)$, whereas $\mathrm{PR}$ of the white line horn was lower $(P=0.000)$ at 160 DIM compared with 30,60 , and $270 \mathrm{DIM}$. The highest $\mathrm{PR}$ of $\mathrm{BCH}$ from the sole and white line was found at 270 DIM when the animals were at pasture (Table 6 ).

The PR of sole horn was higher in the fore right lateral claws compared with the hind left lateral claws at 30 and 60 DIM $(P=0.002$ and 0.019$)$ and higher in the fore lateral claws compared with the hind lateral claws at 160 and hind right lateral claws at 270 DIM ( $P$ $=0.000$ and 0.008 ). The PR of the white line horn was not different between lateral claws at $30(P=0.112)$, $60(P=0.822)$, or 160 DIM $(P=0.145)$. However, $\mathrm{PR}$ of the white line horn was higher $(P=0.002)$ in the hind left lateral claws compared with the fore and hind right lateral claws at 270 DIM (Table 9). The MC of $\mathrm{BCH}$ samples did not differ between fore and hind claws $(P=0.062)$. The mean $\mathrm{MC}$ content of the sole horn was $35.2 \%$ and a positive correlation $(P=0.000)$ was found between MC and the PR of the sole horn (r $=0.83)$.

\section{DISCUSSION}

The PR force-displacement curves showed repeatable distinctive features: a nonlinear concave region, which was followed by a linear increase in force and a peak load. The elastic modulus by tension test showed greater variation in results compared with $\mathrm{PR}$ and this was probably directly related to the smaller number of tests that could be completed due to this technique requiring larger $\mathrm{BCH}$ samples. However, Aranwela et al. (1999) similarly found greater variation within tension tests than PR tests when using these techniques to test the tensile strength of leaves. Due to the nature of the PR test, the measure of EM of the diaphragm has an element of shear in it, differing from the EM measured by tension testing. We decided to perform a tension test, although the variability in the results was greater, because this test is widely used in the literature (Hinterhofer et al., 1998) and results could be compared with findings of other authors. The tension test is commonly used to measure the EM of equine and bovine hoof horn and determines the horn's stiffness. The test mimics some of the forces and deformation the horn is subject to when the animal is walking. The PR test has been used to determine the shear and tensile properties of small specimens and results have been found to be correlated to the results of tension tests (Lewis, 2002). When performing the PR test, small areas can be targeted and tested. The PR test should mimic the forces the claw horn is subjected to when the animal steps on a sharp object, such as stones.

\section{Effect of MC of the Claw Horn on Mechanical Properties of the Sole and White Line Areas}

Although the aim of experiment 1 was to test methodologies that would be used in the clinical study on dairy cows (experiment 2), only claw horn samples of slaughtered beef heifers were available and, therefore, used. Dairy and beef heifers present differences in their claw measurements (Browne et al., 2007) and certain breeds of cattle have a higher prevalence of claw disorders (Huang et al., 1995). They are also often reared in different environments. We did not have information about the rearing conditions of the animals. To minimize differences, we made sure to collect hooves from young animals that did not present any visual alterations. Nonetheless, direct comparisons between the results of both experiments should be avoided. Consid- 


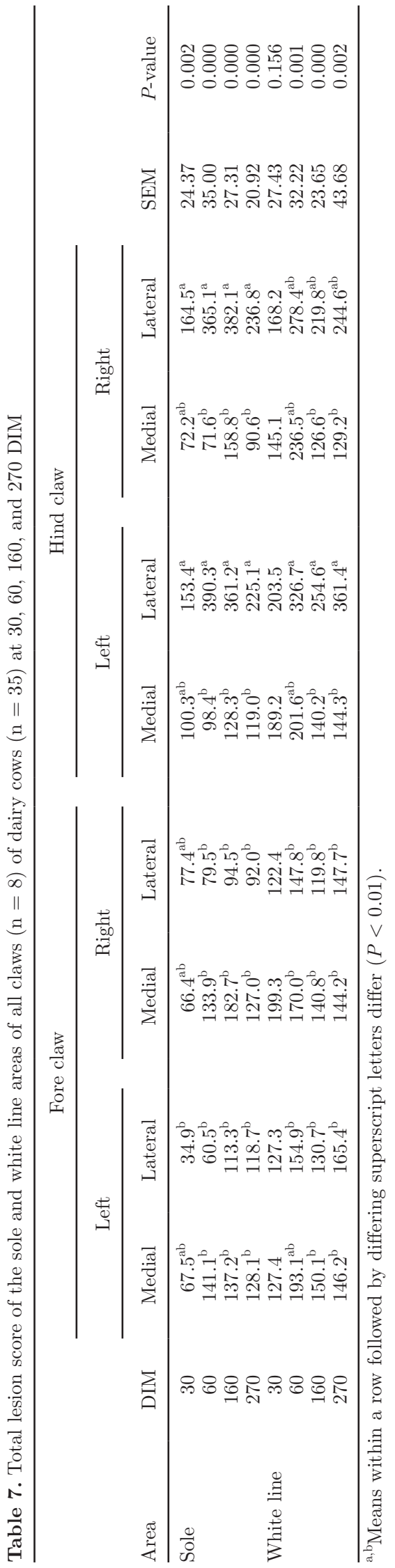

ering that the loss of moisture had a similar influence over the EM of donkey hoof horn (Collins et al., 1998) and bovine claw horn (Baillie et al., 2000), we believe that the loss of moisture content and freezing would have affected the claw horn of dairy cows in a similar way to the claw horn of beef heifers. Consequently, the recommendations about the methodology of testing claw horn samples made in experiment 1, such as keeping samples in sealed plastic bags to avoid moisture loss and length of time until analysis, were adopted in experiment 2 .

In experiment 1 the PR, EM of the diaphragm, and EM measured by tension tests of the sole and white line areas of the bovine claw horn decreased as the MC of the samples increased. When left at room temperature and not stored in plastic bags, the claw horn samples dried out very quickly, changing their mechanical properties. These results demonstrate that the control of the loss of moisture from claw horn samples is clearly of vital importance when testing claw horn tissue. Therefore, to achieve this, claw horn tissue samples should be stored in sealed plastic bags or, according to Collins et al. (1998), wrapped in 3 layers of Parafilm and kept in the refrigerator. In the present experiment, it was found that claw horn samples could be kept in these conditions for up to $8 \mathrm{~d}$ without significant changes in $\mathrm{MC}$ and mechanical properties.

Collins et al. (1998), Hinterhofer et al. (1998), and Baillie et al. (2000) have demonstrated that the MC of claw horn affected the measurements of hardness, EM, bending stiffness, and fracture toughness of the claw horn of different species. The mechanical properties of keratinous materials are strongly influenced by their state of hydration (Kitchener and Vincent, 1987), affecting the different structural layers of the horn, causing the swelling of the matrix in which the keratin fibers are embedded and penetrating the intertubular material. Baillie et al. (2000) found that when the $\mathrm{MC}$ of the bovine claw wall horn was smaller than $10 \%$, a transition occurred from a ductile behavior to a more brittle behavior. The claw horn became stiffer and tougher with decreased hydration levels. A similar transition to a brittle behavior was found in the present experiment when the $\mathrm{MC}$ was lower than $15 \%$.

The bovine sole horn absorbed water quickly during the first $3 \mathrm{~h}$ of soaking in distilled water; thus, the $\mathrm{MC}$ of the horn increased from 29 to $35 \%$ in that period. Borderas et al. (2004) reported that the claw horn absorbed water at a faster rate during the first hour of soaking; $30 \%$ of the total amount of water was absorbed during the first hour and $50 \%$ during the consecutive $4 \mathrm{~h}$ of soaking. In the present experiment, the $\mathrm{MC}$ increased after $3 \mathrm{~h}$ of soaking; however, the PR of the sole claw horn only decreased after $72 \mathrm{~h}$ of soaking. 
Table 8. Mean dorsal length, heel height, abaxial height, growth, wear, and net growth rates of the lateral fore and hind claws of dairy cows $(\mathrm{n}=35)$ at 160 and 270 DIM

\begin{tabular}{|c|c|c|c|c|}
\hline \multirow[b]{2}{*}{ Measurement } & \multicolumn{2}{|c|}{ DIM } & \multirow[b]{2}{*}{ SEM } & \multirow[b]{2}{*}{$P$-value } \\
\hline & 160 & 270 & & \\
\hline \multicolumn{5}{|l|}{ Fore claw } \\
\hline Dorsal length $(\mathrm{cm})$ & 7.25 & 7.77 & 0.11 & 0.000 \\
\hline Abaxial height (cm) & 7.02 & 7.05 & 0.15 & 0.911 \\
\hline Heel height $(\mathrm{cm})$ & 4.94 & 3.81 & 0.16 & 0.000 \\
\hline Growth rate $(\mathrm{cm} / \mathrm{mo})$ & 0.58 & 0.97 & 0.04 & 0.000 \\
\hline Wear rate $(\mathrm{cm} / \mathrm{mo})$ & 0.76 & 0.67 & 0.10 & 0.246 \\
\hline Net growth rate $(\mathrm{cm} / \mathrm{mo})$ & -0.18 & 0.30 & 0.06 & 0.000 \\
\hline \multicolumn{5}{|l|}{ Hind claw } \\
\hline Dorsal length $(\mathrm{cm})$ & 7.30 & 7.84 & 0.07 & 0.000 \\
\hline Abaxial height (cm) & 6.66 & 6.42 & 0.12 & 0.150 \\
\hline Heel height $(\mathrm{cm})$ & 4.20 & 2.90 & 0.13 & 0.000 \\
\hline Growth rate $(\mathrm{cm} / \mathrm{mo})$ & 0.71 & 0.78 & 0.05 & 0.000 \\
\hline Wear rate $(\mathrm{cm} / \mathrm{mo})$ & 0.54 & 0.72 & 0.04 & 0.000 \\
\hline Net growth rate $(\mathrm{cm} / \mathrm{mo})$ & 0.17 & 0.06 & 0.05 & 0.000 \\
\hline
\end{tabular}

Collins et al. (1998) did not find differences between donkey claw horn with physiological MC and hydrated samples. However, Borderas et al. (2004) measured a significant decrease in the hardness of the sole, white line, and wall horn after soaking the claws in water for $4 \mathrm{~h}$. They used a Shore durometer, which once placed flat on the materials surface, pressed a spring-loaded probe into the surface with a constant force.

The mean MC of bovine sole horn presented by van Amstel et al. (2004) and Hinterhofer et al. (2005a) of 32.1 and $29.36 \%$, respectively, is very similar to the mean MC of the sole claw horn of $29.05 \%$ in the present experiment. The mean EM by tension testing of the sole area of the claw horn from beef heifers with physiological moisture content was $116.9 \mathrm{~N} / \mathrm{mm}^{2}$ (SEM 39.5) and was slightly smaller than the EM of the sole horn area with physiological moisture content presented by Hinterhofer et al. (2005a) of 172.1 (SD $137.3 \mathrm{~N} / \mathrm{mm}^{2}$ ).

Bonser et al. (2003) reported that the increase in the $\mathrm{MC}$ of the claw horn lead to an increase of the rate of wear of the horn on rough surfaces. On smooth sur- faces, the rate of wear decreased with higher $\mathrm{MC}$ of the horn. Those findings show a complex interaction between the mechanical properties of the claw horn, MC, and the friction and wear caused by different surfaces, indicating the importance of controlling environmental moisture levels when cows are housed on hard surfaces such as concrete floors.

\section{Effect of Freezing on Mechanical Properties of the Sole and White Line Areas}

In the present study, freezing caused an increase in the EM of the sole claw horn when samples were frozen for $30 \mathrm{~d}$. However, no significant decrease was observed in the MC of the samples. Kasapi and Gosline (1999) did not find a significant effect of freezing of equine claw wall samples on the bending modulus of the samples. In their experiment, samples were frozen at $-10^{\circ} \mathrm{C}$ for $10 \mathrm{~min}$. Similarly, in the present experiment, freezing for shorter periods of 1 and $7 \mathrm{~d}$ had no significant effect on PR, EM of the diaphragm, and EM measured

Table 9. Puncture resistance $(\mathrm{N})$ of the sole and white line claw horn of the lateral fore and hind claws of dairy cows $(\mathrm{n}=35)$ at $30,60,160$, and 270 DIM and moisture content (MC) at 160 DIM

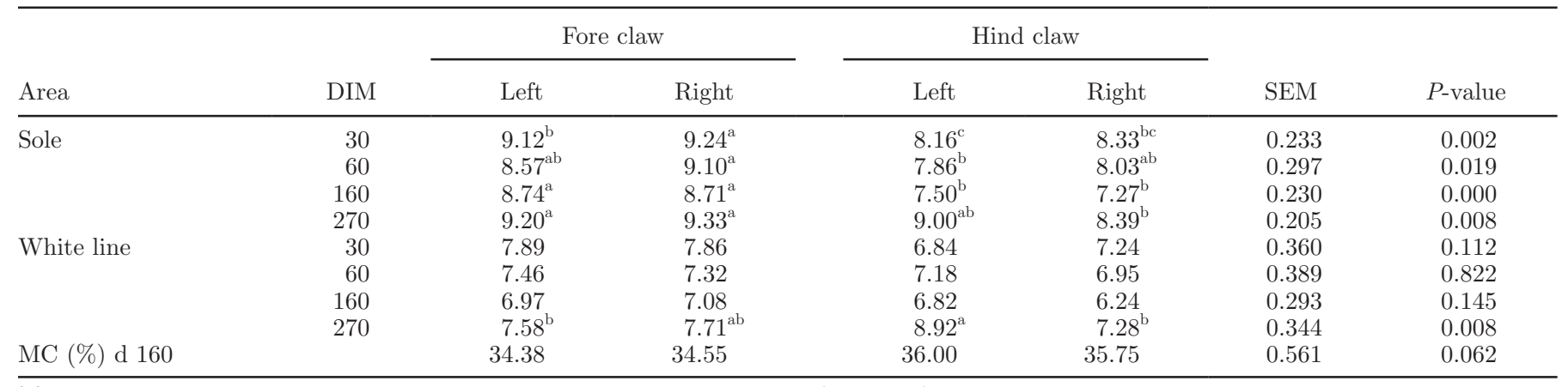

\footnotetext{
${ }^{\mathrm{a}-\mathrm{c}}$ Means within a same row followed by differing superscript letters differ $(P<0.05)$
} 
through tension tests of the sole and white line areas. Thus, short-term freezing was found not to affect the mechanical properties of claw horn samples. Freezing for longer periods (i.e., $30 \mathrm{~d}$ ) is not recommended when testing $\mathrm{BCH}$ samples for its mechanical properties due to the reported changes in EM.

\section{Locomotion and Lesion Scores in the Postpartum Period}

The locomotion score and lesion scores of the sole area of the claw horn increased during the postpartum period. Several authors have reported similar findings (Chaplin et al., 2000; Offer et al., 2000). The hormonal and metabolic changes associated with parturition and the consequent softening of the collagen fibers that connect the third phalanx to the horn capsule (Tarlton et al., 2002) and postural changes at the beginning of the lactation period (Chapinal et al., 2009) are believed to be the major contributory factor in the development of claw lesions. The lesion scores of the white line area of the claw horn were constantly high, but no significant increase was observed in the postpartum period. Le Fevre et al. (2001) found white line lesions to be more evenly distributed between claws when compared with sole lesions. Locomotion score and lesion scores of the sole area decreased again at the end of the lactation period (180 and $270 \mathrm{~d}$ postpartum) when cows were turned out to pasture. Similarly, Singh et al. (1993) found lower incidences of lameness when cows were turned out to pasture during the spring and summer. This decrease in lesion scores would probably be related to several factors, rather than any one single effect, which include change in environment, lower metabolic stress that cows are subjected to later in lactation, and longer daylight and the more favorable conditions for claw horn growth and keratinization (MacCallum et al., 2002). At pasture, the cows will spend less time standing in slurry, reducing the softening effect that slurry has on the claw horn and the severity of claw horn lesions (Webster, 2001). A yielding surface, such as grass, has been found to distribute the load more evenly over the weight-bearing surface of the individual claw and between the lateral and medial claw of each limb (Webster, 2001). At pasture, cows spend also a longer period of time lying and had fewer changes between lying and standing postures when compared with cows in cubicles. Increased lying time was related to lower lameness incidence (Singh et al., 1993).

The locomotion score at d 90 DIM was greater for cows with greater number of lactations. Cows with 5 or more lactations presented more cases of sole ulcers (4 out of 6 cases) that were related to high locomotion scores (4) and were, in general, more tender on their feet (locomotion score 2 or more). However, the fit of the data was low $\left(\mathrm{R}^{2}=0.19\right)$ and changes observed in the locomotion score were not observed in the lesion score and puncture resistance. We also expected to find a higher lesion score and lower PR on cows with higher parity. Most animals presented high lesion scores, even animals with low locomotion scores, and locomotion and lesion scores were only correlated at 270 DIM. The sole heel junction (zone 4 of the IFM) is the area where sole ulcers form and presents the highest lesion scores. Due to the difficulty in obtaining samples from the sole heel junction in the correct size required for PR testing ( $>20 \mathrm{~mm}$ width and length), the PR was not measured in this zone. It is possible that differences between parity would have been evident if samples from the sole heel junction could have been tested.

During the postpartum period, the hind lateral claws had a significantly higher lesion score for the sole area when compared with fore and medial hind claws. Similar results were reported by Offer et al. (2000) and Le Fevre et al. (2001). Due to the conformation of the coxofemoral joint, the cow has been found to be more able to relieve weight from the fore both medial and lateral claws than from the hind claws and the alteration of forces (i.e., the difference of the minimum to the maximum load, rather than the absolute load) was considered to be greater in the hind lateral claws (van der Tol et al., 2002). Moreover, at parturition, the weight of the udder is carried on the hind legs and the conformation of the udder has been found to force the cow to have a wider stance, causing an increased weight bearing on the lateral hind claws (Chapinal et al., 2009). White line lesion scores were significantly higher for the hind left lateral claws when compared with fore claws and this difference was not observed for the hind right lateral claws. The higher scores presented by the hind left lateral claws may potentially be related to the left hand turn that cows have to make when leaving the parlor in the housing system at the University of Plymouth farm.

\section{Claw Measurements in the Postpartum Period}

The growth rates of the hind claws $(0.71 \mathrm{~cm} / \mathrm{month})$ of the animals in the present study were higher than the rates reported by Chaplin et al. (2000) and Offer et al. (2000) of 0.417 to $0.540 \mathrm{~cm} /$ month for cows kept in a cubicle system. Livesey and Laven (2007) reported similar rates $(0.633 \mathrm{~cm} /$ month $)$ for heifers kept in cubicles in the wk 6 to 12 postpartum. The growth rates of fore and hind claws increased when cows were turned out to pasture in the present study and wear rates increased for the hind claws but not for fore claws. The increase in wear rates of hind claws when animals were 
at pasture may be related to increase in the walking distances and rough walking surfaces. Increase in growth rate when at pasture could be related to a combination of several factors, including photoperiod, a reaction to the increase in wear rate, and changes in the underfoot environment from the concrete flooring to pasture (Clark and Rakes, 1982; Vokey et al., 2001; MacCallum et al., 2002). The fore claws had negative net growth rates when the cows were housed and, apparently, a compensatory growth rate when at pasture. This would indicate the potential for sole thinning in indoor housing with concrete flooring leading to a decrease in the impact absorption and protection of the corium, which could increase sole bruising. Thin soles have been found to increase the hazard for the occurrence of sole and toe ulcers (Sanders et al., 2009). For the hind claws the net growth rates were higher when animals were housed compared with when at pasture. Conversely, Vokey et al. (2001) reported negative net growth rates of hind claws when animals were housed on concrete floors.

In the present study, the length of the claws and the height of the heel differed significantly between d 160 and 270 postpartum. The claws were longer and the height of the heel shorter when cows were at pasture, which was most likely due to the higher growth rate while at pasture compared with winter housing. The softer heel horn may have worn out faster due to the increase in the walking distances and rough walking surfaces. Boelling and Pollott (1998) and Offer et al. (2000) reported smaller claw angles and longer claws when animals were out at pasture when compared with the winter housing period.

\section{The Effect of DIM and the Lesion Score on the $P R$ of $B C H$}

In the present experiment, the $\mathrm{PR}$ of the sole and white line areas of the claw horn decreased during the postpartum period, reaching the lowest level at d 160 postpartum when lesion scores of the sole area was at the highest. Other factors that may have affected the measurements of PR could have been the amount of time the animals were housed and the length of time that the claws were exposed to slurry and concrete flooring. The PR increased as the lesions score decreased at the end of lactation and this coincided with the period when cows were turned out to pasture. The environment change, from a cubicle system with concrete floor to pasture, and the late lactation period could both have had a positive effect on the PR of the horn.

The PR of the sole and white line areas was consistently significantly higher for the fore claws when compared with the hind claws. Schmid (1995) reported higher values of Shore D hardness and tensile strength for the fore claws when compared with the hind claws. Results were related to a higher MC of hind claws when compared with fore claws, contrary to the results of the present experiment were no differences of the MC between fore and hind claws were measured. Hinterhofer et al. (2005b) did not find differences in the hardness between the fore and hind claws. Puncture resistance was expected to be lower in the hind lateral claws compared with the medial claws because the lateral ones had consistently the highest scores for lesions. However, in this experiment only samples from the lateral claws were analyzed and that difference could not be measured. We will aim to measure differences between lateral and medial claws in future experiments.

In our study, the PR and EM were found to be lower in the white line area of the horn when compared with the sole horn tissue, thus indicating the white line to be weaker and less elastic. Testing the white line area of the weight-bearing surface of the bovine claw, Budras et al. (1996) reported mean hardness values obtained with the use of the ball-impact method of $5.1 \mathrm{~N} / \mathrm{mm}^{2}$ for the cap-horn area and of $6.9 \mathrm{~N} / \mathrm{mm}^{2}$ for the terminal horn area. These values were significantly lower than the values for the sole horn $\left(12.9 \mathrm{~N} / \mathrm{mm}^{2}\right)$ and for the wall horn $\left(27.5 \mathrm{~N} / \mathrm{mm}^{2}\right)$. A high incidence of alterations in the horn formation has been found at the white line area (Mulling et al., 1994) and the abaxial part of the white line, where the soft horn bonds to the harder coronary horn, has been found to be especially susceptible to tearing (Budras et al., 1996).

An association between horn structural strength and hemorrhage level has not been previously demonstrated. Borderas et al. (2004) found significant negative correlations between claw hardness measured with a durometer and hemorrhages of the sole and white line areas, heel erosion and sole ulcers. Clearly, claw horn with hemorrhages was inferior in terms of mechanical properties (i.e., strength) and would provide less cushioning effect than horn without hemorrhages, potentially increasing the trauma of the corium and basal cell layers of the dermis. A horn with less elasticity and hardness values may wear faster, depending on the walking surface, thus decreasing sole thickness and again increasing the risk for trauma of the corium.

\section{CONCLUSIONS}

The PR test proved to be an adequate method for the measurement of changes in the mechanical properties of the claw horn tissue samples collected from the sole and white line areas of the claws of beef heifers and lactating dairy cows. The PR of claw horn from the white line was significantly lower than that collected from the sole. The experiment on claw horn from beef heifers 
showed that it is important to prevent the dehydration of the samples when testing the mechanical properties of the claw horn tissue at physiological moisture levels. The claw horn total lesion score and the locomotion score increased during lactation. The locomotion score peaked at approximately 120 DIM and decreased by 160 DIM. The claw horn total lesion score was highest at 60 DIM for the white line and at 160 DIM for the sole horn. The increase in hemorrhage levels and MC of the claw horn samples had a significant effect on the mechanical properties of claw horn tissue. Hemorrhage of sole horn was associated with a decrease in the PR. This may well affect the cushioning, resistance to mechanical damage, and wear capability of $\mathrm{BCH}$, increasing the risk of foreign body penetration, infection, and trauma of the underlying corium. Further research is needed to study factors that have an influence on the moisture content and, consequently, the PR and $\mathrm{EM}$ of the $\mathrm{BCH}$, such as housing conditions, and also study the changes occurring on the claw horn structural strength of heifers during the first lactation.

\section{ACKNOWLEDGMENTS}

We thank Peter Russel and the technical support team at the Agricultural Laboratories of the University of Plymouth (Plymouth, UK): Patrick Bugg and Ashley, for their help and assistance, and the farm staff of the University of Plymouth farm (Seale Hayne, Newton Abbot, UK): Richard Newington and Andy Harrison. We are grateful to Charles Brennan (Lincoln University, Lincoln, New Zealand), John Summerscales of Plymouth University (Plymouth, UK), Richard Bonser of Reading University (Reading, Berkshire, UK), J. F. V. Vincent of Bath University (Bath, UK), Chris Smith and Xuejun Ren of Exeter University (Exeter, Devon, UK) for their advice on mechanical testing, and Linton Winder (Department for Natural Sciences, UNITEC, Auckland, New Zealand) for reading the manuscript.

\section{REFERENCES}

Aranwela, N., G. Sanson, and J. Read. 1999. Methods of assessing leaffracture properties. New Phytol. 144:369-393.

Baillie, C., C. Southam, A. Buxton, and P. Pavan. 2000. Structure and properties of bovine claw horn. Adv. Compos. Lett. 9:101-113.

Barker, Z. E., J. R. Amory, J. L. Wright, S. A. Mason, R. W. Blowey, and L. E. Green. 2009. Risk factors for the increased rates of sole ulcers, white line disease and digital dermatitis in dairy cattle from twenty-seven farms in England and Wales. J. Dairy Sci. 92:1971-1978.

Blake, A. 1982. Plates and flanges - Design fundamentals. Pages 397415 in Practical Stress Analysis in Engineering Design. Marcel Dekker Inc., New York, NY.

Boelling, D., and G. E. Pollott. 1998. Locomotion, lameness, claw and leg traits in cattle. I. Phenotypic influences and relationships. Livest. Prod. Sci. 54:193-203.
Bonser, R. H. C., J. W. Farrent, and A. M. Taylor. 2003. Assessing the frictional and abrasion-resisting properties of hooves and claws. Biosystems Eng. 86:253-256.

Borderas, T. F., B. Pawluczuk, A. M. de Passillé, and J. Rushen. 2004. Claw hardness of dairy cows: Relationship to water content and claw lesions. J. Dairy Sci. 87:2085-2093.

Browne, M. P., D. W. L. Hukins, J. M. S. Skakle, C. H. Knight, K. A. K. Hendry, C. J. Wilde, and H. Galbraith. 2007. X-ray diffraction patterns and anatomical properties of claw tissues of beef and dairy cattle. J. Agric. Sci. 145:623-633.

Budras, K. D., Ch. Mülling, and A. Horowitz. 1996. Rate of keratinization of the wall segment of the claw and its relation to width and structure of the zona alba (white line) with respect to claw disease in cattle. Am. J. Vet. Res. 57:444-455.

Capion, N., S. M. Thamsborg, and C. Enevoldsen. 2008. Conformation of hind legs and lameness in Danish Holstein heifers. J. Dairy Sci. 91:2089-2097.

Chapinal, N., A. M. de Passillé, and J. Rushen. 2009. Weight distribution and gait in dairy cattle are affected by milking and late pregnancy. J. Dairy Sci. 92:581-588.

Chaplin, S. J., H. E. Ternent, J. E. Offer, D. N. Logue, and C. H. Knight. 2000. A comparison of claw lesions and behaviour in pregnant and early lactation heifers at housing. Vet. J. 159:147-153.

Clark, A. K., and A. H. Rakes. 1982. Effect of methionine hydroxy analog supplementation on dairy cattle claw and composition. J. Dairy Sci. 65:1493-1502.

Collins, S. N., B. C. Cope, L. Hopegood, R. J. Latham, R. G. Linford, and J. D. Reilly. 1998. Stiffness as a function of moisture content in natural materials: Characterisation of hoof horn samples. J. Mater. Sci. 33:5185-5191.

Hinterhofer, C., V. Apprich, J. C. Ferguson, and C. Stanek. 2005a. Elastic properties of hoof horn on different positions of the bovine claw. Dtsch. Tierärztl. Wochenschr. 112:142-146.

Hinterhofer, C., Ch. Stanek, and K. Binder. 1998. Elastic modulus of equine claw horn, tested in wall samples, sole samples and frog samples at varying levels of moisture. Berl. Munch. Tierärztl. Wochenschr. 111:217-221.

Hinterhofer, C., M. Zöscher, C. Gabler, and C. Stanek. 2005b. The hardness of horn in different segments of the bovine claw. Berl. Munch. Tierarztl. Wochenschr. 118:334-340.

Huang, Y. C., R. D. Shanks, and G. C. McCoy. 1995. Evaluation of fixed factors affecting hoof health. Livest. Prod. Sci. 44:115-124.

Kasapi, M. A., and J. M. Gosline. 1999. Micromechanics of the equine claw wall: Optimizing crack control and material stiffness through modulation of the properties of keratin. J. Exp. Biol. 202:377-391.

Kitchener, A., and J. F. V. Vincent. 1987. Composite theory and the effect of water on the stiffness of horn keratin. J. Mater. Sci. 22:1385-1389.

Le Fevre, A. M., D. N. Logue, J. E. Offer, I. McKendrick, and G. Gettinby. 2001. Correlations of measurements of subclinical claw horn lesions in dairy cattle. Vet. Rec. 148:135-138.

Leach, K. A., D. N. Logue, J. M. Randall, and S. A. Kempson. 1998. Claw lesions in dairy cattle: Methods for assessment of sole and white line lesions. Vet. J. 155:91-102.

Lewis, G. 2002. Key issues involved with the use of miniature specimens in the characterization of the mechanical behavior of polymeric biomaterials - A review. J. Biomed. Mater. Res. 63:455466.

Livesey, C. T., and R. A. Laven. 2007. Effects of housing and intake of methionine on the growth and wear of hoof horn and the conformation of the hooves of first-lactation Holstein heifers. Vet. Rec. 160:470-476.

MacCallum, A. J., C. H. Knight, K. A. K. Hendry, C. J. Wilde, D. N. Logue, and J. E. Offer. 2002. Effects of time of the year and reproductive state on the proliferation and keratinisation of bovine claw cells. Vet. Rec. 151:285-289.

MAFF (Ministry of Agriculture, Fisheries and Food). 1986. Analysis of Agricultural Materials RB429. ADAS, London, UK.

Manson, F. J., and J. D. Leaver. 1988. The influence of concentrate amount on locomotion and clinical lameness in dairy cattle. Anim. Prod. 47:185-190. 
Mülling, Ch., H. Bragulla, K. D. Budras, and S. Reese. 1994. Structural factors influencing horn quality and sites of predilection at the ground surface of the cattle hoof. Schweiz. Arch. Tierheilkd. 136:49-57.

Mulling, Ch. K. W., and K.-D. Budras. 2002. Morphology of the dermo-epidermal junction of the bovine claw with reference to its biological function. Wien. Tierärztl. Monatsschr. 89:188-196.

Offer, J. E., D. N. McNulty, and D. N. Logue. 2000. Observations of lameness, claw conformation and development of lesions in dairy cattle over four lactations. Vet. Rec. 147:105-109.

Patan, B., and K. D. Budras. 2003. Segment specificity of the equine claw-Part 2: Correlation of horn structure and mechanical physical horn properties in the different segments of the hoof. Pferdeheilkunde 19:177-184.

Sanders, A. H., J. K. Shearer, and A. De Vries. 2009. Seasonal incidence of lameness and risk factors associated with thin soles, white line disease, ulcers, and sole punctures in dairy cattle. J. Dairy Sci. 92:3165-3174.

Schmid, M. 1995. Der Einfluss von Biotin auf die Klauenhornqualität beim Rind. PhD Thesis. University of Zurich, Zurich, Switzerland.

Shearer, J. K., E. Belknap, S. Berry, C. Guard, K. Hoblet, E. Hovingh, G. Kirksey, A. Langill, and S. R. van Amstel. 2002. The standardization of input codes for capture of lameness data in dairy records. Pages 346-349 in Proc. 12th Int. Symp. Lameness Rumin., Orlando, FL. J. K. Shearer, ed.
Singh, S. S., W. R. Ward, K. Lautenbach, J. W. Hughes, and R. D. Murray. 1993. Behaviour of first lactation and adult dairy cows while housed and at pasture and its relationship with sole lesions. Vet. Rec. 133:469-474.

Tarlton, J. F., D. E. Holah, K. M. Evans, S. Jones, G. R. Pearson, and A. J. F. Webster. 2002. Biomechanical and histopathological changes in the support structures of bovine hooves around the time of first calving. Vet. J. 163:196-204.

Telezhenko, E., C. Bergsten, M. Magnusson, and C. Nilsson. 2009 Effect of different flooring systems on claw conformation of dairy cows. J. Dairy Sci. 92:2625-2633.

van Amstel, S. R., J. K. Shearer, and F. L. Palin. 2004. Moisture content, thickness and lesions of the sole horn associated with thin soles in dairy cattle. J. Dairy Sci. 87:757-763.

van der Tol, P. P. J., J. H. M. Metz, E. N. Noordhuizen-Stassen, W. Back, C. R. Braam, and W. A. Weijs. 2002. The pressure distribution under the bovine claw during square standing on a flat substrate. J. Dairy Sci. 85:1476-1481.

Vokey, F. J., C. L. Guard, H. N. Erb, and D. M. Galton. 2001. Effect of alley and stall surfaces on indices of claw and leg health in dairy cattle housed in a free-stall barn. J. Dairy Sci. 84:2686-2699.

Webster, A. J. F. 2001. Effects of housing and two forage diets on the development of claw horn lesions in dairy cows at first calving and first lactation. Vet. J. 162:56-65. 